\title{
Crepidobothrium eirasi n. sp. (Cestoda: Proteocephalidae), a parasite of the siluroid fish Phractocephalus hemioliopterus (Schneider, 1801) (Pisces: Pimelodidae) from the Brazilian Amazon.
}

\author{
Amilcar Arandas REGO* \& Alain de CHAMBRIER** \\ * Instituto Oswaldo Cruz, Department of Helmintology, \\ PO Box 926, 20001 Rio de Janeiro, Brazil. \\ ** Muséum d'Histoire naturelle, \\ PO Box 6434, 1211 Geneva 6, Switzerland.
}

Crepidobothrium eirasi n. sp. (Cestoda: Proteocephalidae), a parasite of the siluroid fish Phractocephalus hemioliopterus (Schneider, 1801) (Pisces: Pimelodidae) from the Brazilian Amazon. - A new species of Proteocephalid cestode, Crepidobothrium eirasi n. sp. is described from Phractocephalus hemioliopterus (Schneider, 1801), a freshwater siluriform fish from the Amazon. This is the first report of Crepidobothrium in fish. The other known species are parasites of South American snakes. Crepidobothrium eirasi $\mathrm{n}$. sp. is characterized mainly by their small size (with only 7-12 segments), by the notched, heart-shaped suckers, by the posterior ventral appendix of the proglottis, by the vitelline follicles, located between and external to the longitudinal muscle fibres (paramuscular), and by the absence of vitellaria in the preporal region of proglottis.

Key-words: Crepidobothrium eirasi n. sp. - Proteocephalidae - Phractocephalus hemioliopterus - (Pisces: Pimelodidae) - Brazil.

\section{INTRODUCTION}

The base of the taxonomy of the neotropical cestode family Monticelliidae parasitizing freshwater fishes was established by WoODLAND (1933a, b, c; 1934a, b, c; $1935 \mathrm{a}, \mathrm{b}, \mathrm{c})$. The presence of a mixture of several species in his so-called type material as well as old insufficient descriptions made indispensable a collection of recent material. For this reason, the authors went to Itacoatiara, Amazonas State, Brasil (one of the Woodland's type locality) in September 1992, where numerous proteocephalideans tapeworms were collected. Among three proteocephalideans species found in the siluroid fish Phractocephalus hemioliopterus, one proved to belong to a new

\footnotetext{
* Research fellow of CNPq.

Manuscript accepted 14.06.94.
} 
species and we attributed it provisionnally to the genus Crepidobothrium. This genus comprises five species parasite of neotropical snakes (Viperidae and Boidae) (DE CHAMBriER 1989a, b).

We found, mixed to the original material of Myzophorus pirarara Woodland, 1935 (parasite of the same host-species) numerous specimens of Crepidobothrium eirasi $\mathrm{n} . \mathrm{sp}$.

\section{MATERIAL AND METHODS}

Seven specimens of Phractocephalus hemioliopterus were collected and examined. They were dissected in the field immediately after death. Different portions of the entire split digestive tract were fixed with hot $4 \%$ neutral formaldehyde solution. The parasitic worms were stained with Mayer's hydrochloric carmin and with Delafield hematoxylin, then differentiated in acid alcohol, deshydrated in ethanol, cleared in Eugenol (clove oil), and mounted in Canada balsam. Transverse sections, five to twelve $\mu \mathrm{m}$ thick, were stained with Weigert's hematoxylin and counterstained with eosin. The parasites are stored in the Muséum d'Histoire naturelle, Geneva (MHNG), in the Instituto Oswaldo Cruz, Rio de Janeiro (IOC) and in the Natural History Museum, London (BMNH).

All measurements are in micrometres unless otherwise stated; Abbreviations: $\mathrm{m}=$ mean, $\mathrm{n}=$ number of measurements used, $\mathrm{CV}=$ coefficient of variation .

\section{Crepidobothrium eirasi n. sp.}

Material studied: Brazil, Amazon river at Itacoatiara (AM), in Phractocephalus hemioliopterus (Schneider, 1801) 15-25.9.1992, leg A. de Chambrier \& A.A. Rego: Holotype MHNG No. 992.144; 10 paratypes No. MHNG 992.145-154; one paratype IOC No. 33128; one paratype BMNH No. 1994.5.23.1; other material: slides: MHNG No. 992.155-157; 992.159-160; alcohol: MHNG No. 992.158.

Brazil, Amazon river between Manaus and Gurupa, Woodland's material, syntypes of Myzophorus pirarara*: BMNH 1965.2.23.146-155, 1965.2.23.156-158, 1983.5.17.2-10.

Site of infection: intestine; Prevalence: $86 \%, \mathrm{n}=7$ hosts; intensity: up to more than 100 specimens.

Derivatio nominis: The new species is named in honour of Professor Jorge Eiras, from the Oporto University (Portugal) for his contribution to the knowledge of Brasilian fish pathology.

* We found, mixed to the original material of Myzophorus pirarara Woodland, 1935, respectively 16 specimens on slide and 75 specimens in alcohol of Crepidobothrium eirasi $\mathrm{n}$. sp.

\section{FIGS 1-3}

Crepidobothrium eirasi n. sp. 1. Entire worm, paratype. 2. Mature proglottis, paratype, ventral view, showing the posterior appendix on each side. 3. Gravid proglottis, holotype, dorsal view. The eggs are not figured. Scale: $1=500 \mu \mathrm{m} ; 2-3=250 \mu \mathrm{m}$. 

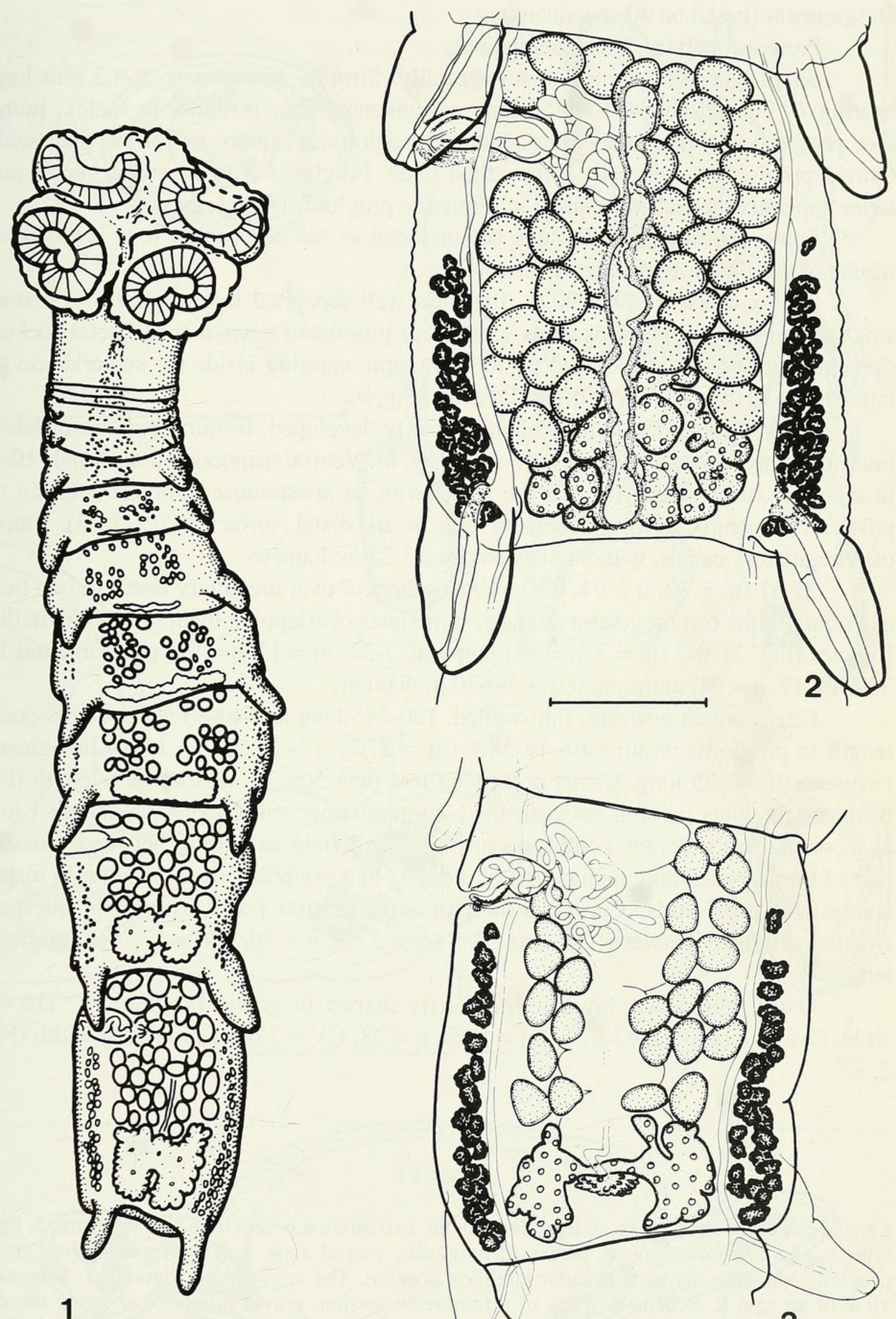

1

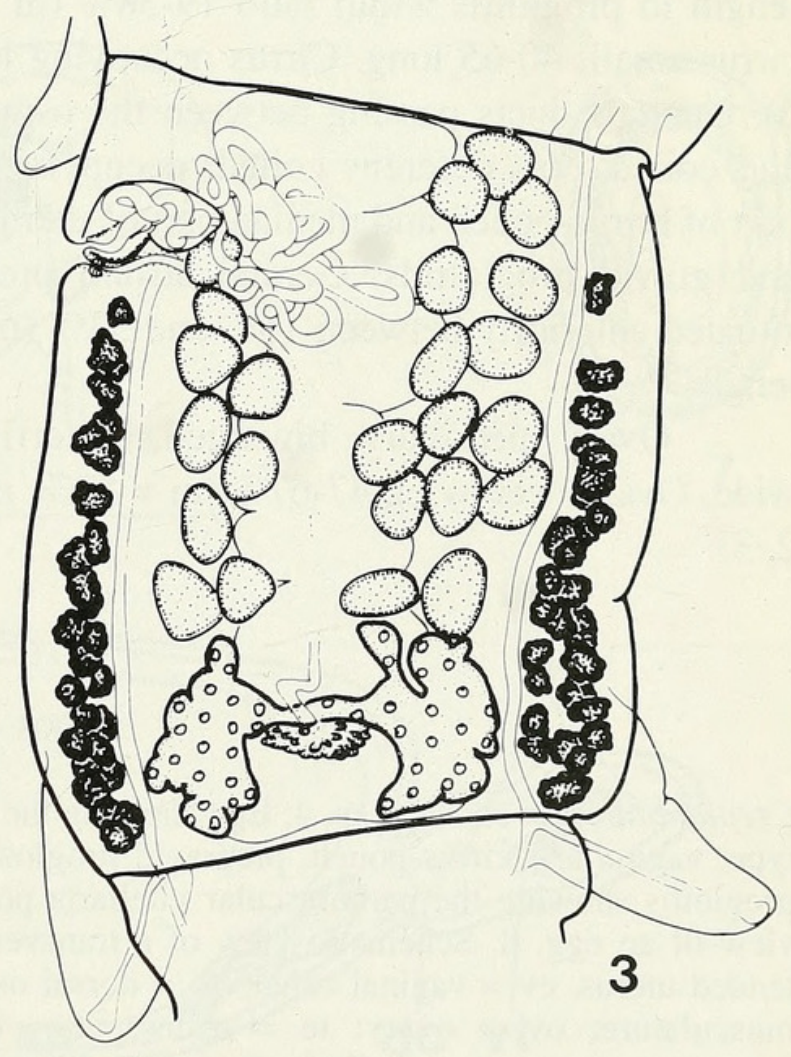




\section{DESCRIPTION (based on 30 specimens)}

Proteocephalidae, Proteocephalinae.

Small worms, flattened dorso-ventrally. Strobila acraspedote, 2-8.5 mm long, bearing 7-12 proglottides. 100-150 long unsegmented zone posterior to scolex. Immature proglottides wider than long. Mature proglottides square or longer than wide. Gravid proglottides generally longer than wide. Proglottis with a ventral lateral posterior appendix on each side, small in immature proglottis (Figs 1, 2, 3).

Some abnormal proglottides not included in the description (e.g. with hypertrophy of vitelline follicles) were present.

Scolex massive, 495-990 in diameter, well separated from strobila, with some small apical tegumental folds (Figs 1,9). Four prominent heart-shaped lateral suckers, opening anteriorly, with notched posterior margin, entering inside the suctorial cavity; latter 180-410 $(\mathrm{m}=270, \mathrm{n}=70)$ in diameter (Fig. 9).

Internal longitudinal musculature weakly developed, forming bundles of lateral muscular fibres more visible on each side (Fig. 6). Ventral osmoregulatory canals 10-40 in diameter (more than 100 into the neck) with an anastomosed portion entering the posterior appendix, which seems to end at its distal surface (Figs 2, 3). Dorsal osmoregulatory canals, without anastomoses, 5-25 in diameter.

21-51 $(\mathrm{m}=32, \mathrm{n}=94, \mathrm{CV}=19.8)$ spherical oval medullary testes in one field, extending to the osmoregulatory canals, sometimes overlapping them, reaching vitelline follicles (Fig. 2). 0-7 ( $\mathrm{m}=3, \mathrm{n}=94)$ preporal, $7-22(\mathrm{~m}=12, \mathrm{n}=94)$ postporal and 10$30(\mathrm{~m}=17, \mathrm{n}=94)$ antiporal testes, 60-70 in diameter.

Cirrus-pouch piriform, thin-walled, 120-245 long and 40-80 wide. Cirrus-pouch length to proglottis width ratio $19-38 \%(\mathrm{~m}=27 \%, \mathrm{n}=28, \mathrm{CV}=15.6)$. Invaginated cirrus small, 40-65 long. Cirrus occupying less than $50 \%$ of cirrus-pouch length (Fig. 5). Genitals ducts passing between the osmoregulatory canals. Ejaculatory duct long and coiled. Vas deferens coiled, occupying round field extending between proximal part of cirrus-pouch and median part of uterus, often extending over the latter in mature and gravid proglottids. Genital atrium present. Genital pores irregularly alternate, situated anteriorly between $16 \%$ and $33 \%(\mathrm{~m}=23 \%, \mathrm{n}=30, \mathrm{CV}=17.2)$ of proglottid length.

Ovary medullary, biwinged, butterfly-shaped in gravid proglottides, 210-475 wide. Ovary occupying $47-67 \%(\mathrm{~m}=57 \%, \mathrm{n}=28, \mathrm{CV}=7.6)$ of proglottid width (Figs $2,3)$.

\section{FIGS 4-8}

Crepidobothrium eirasi n. sp. 4. Egg showing the two internal polar circle-like structure. 5. Paratype, vagina and cirrus-pouch, pregravid proglottis, ventral view. 6. Transverse section, gravid proglottis showing the paramuscular vitellaria position. The eggs are not figured. 7. Schematic view of an egg. 8. Schematic view of a transverse section, gravid proglottis showing the distended uterus. $\mathrm{cv}=$ vaginal $\mathrm{canal} ; \mathrm{dc}=$ dorsal osmoregulatory canals; $\mathrm{li}=$ internal longitudinal musculature; $\mathrm{ov}=$ ovary; te $=$ testes; $\mathrm{ut}=$ uterus; $\mathrm{vc}=$ ventral osmoregulatory canals; $\mathrm{vt}=$ vitellaria. Scale: $4=50 \mu \mathrm{m} ; 5=125 \mu \mathrm{m} ; 6=100 \mu \mathrm{m}$. 


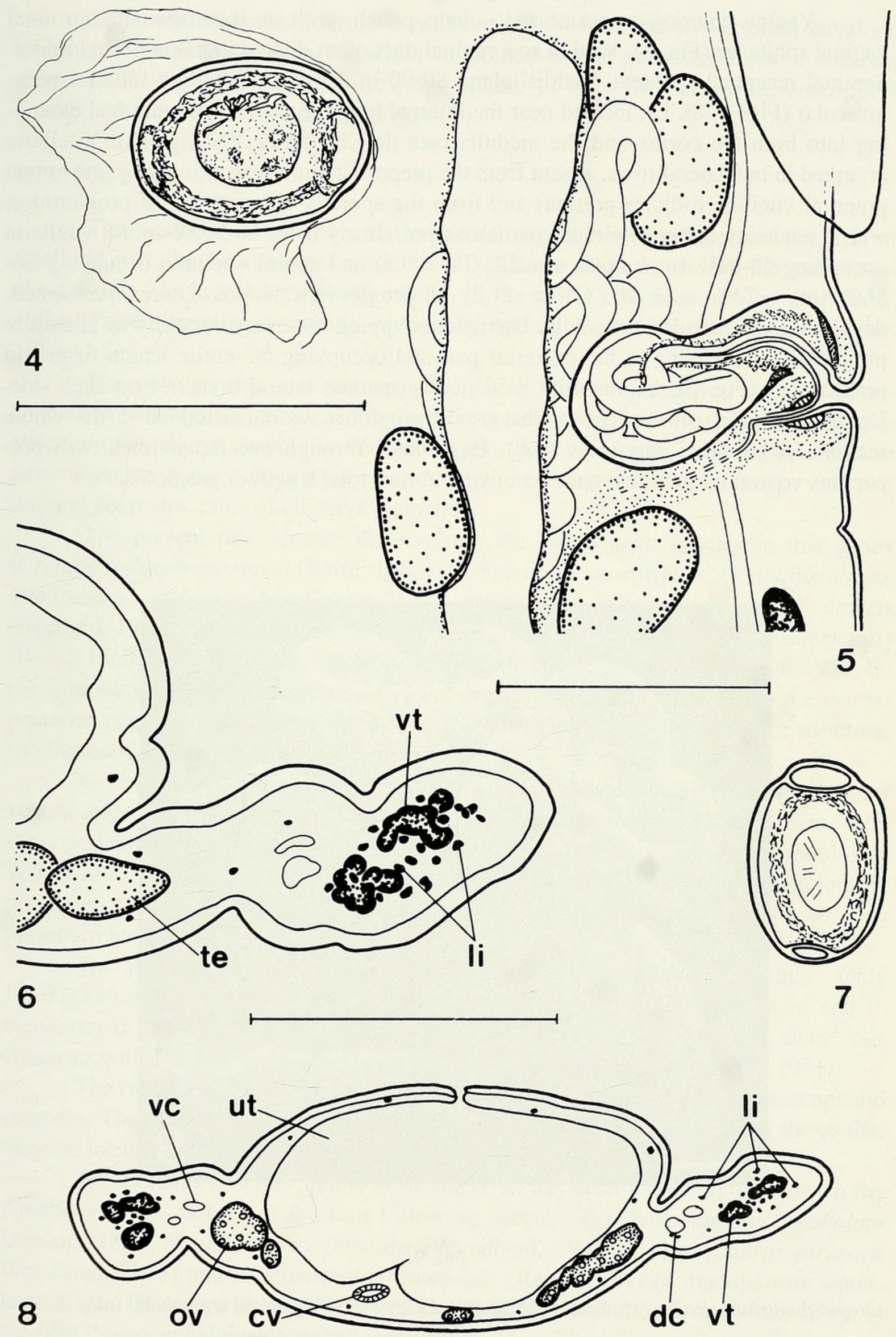


Vagina anterior or posterior to cirrus-pouch, with an inconspicuous terminal vaginal sphincter (Fig. 5). Vagina and vaginal duct often dilated in mature proglottides. Seminal receptacle present. Mehlis' gland 80-90 in diameter. Vitelline follicles paramuscular (Figs 6, 8), i.e. located near the internal longitudinal musculature and extending into both the cortex and the medulla (see de Chambrier 1990, p. 92). Vitellaria arranged in two lateral rows, absent from the preporal region (exceptionnally one to two preporal vitelline follicles present) and from the aporally anterior part of proglottides, with a tendency to become more numerous posteriorly (Figs 2, 3). Postporal vitellaria occupying $54-81 \%(\mathrm{~m}=66 \%, \mathrm{n}=22, \mathrm{CV}=9.5)$ and aporal vitellaria occupying 56$86 \%(\mathrm{~m}=74 \%, \mathrm{n}=20, \mathrm{CV}=11.2)$ of proglottides length. Uterus preformed, developing diverticula in medulla. Uterus overlapping the ovary ventrally in immature proglottides, extending to the posterior part and occupying the entire length of gravid proglottides (Fig. 3). Uterus with 8-12 poorly marked lateral branches on each side. Uterus occupying up to $70 \%$ of the gravid proglottis width, distended in the whole median longitudinal part (Figs 6,8). Eggs layed through one (sometimes two) precocious ventral longitudinal split occupying almost total length of proglottis.

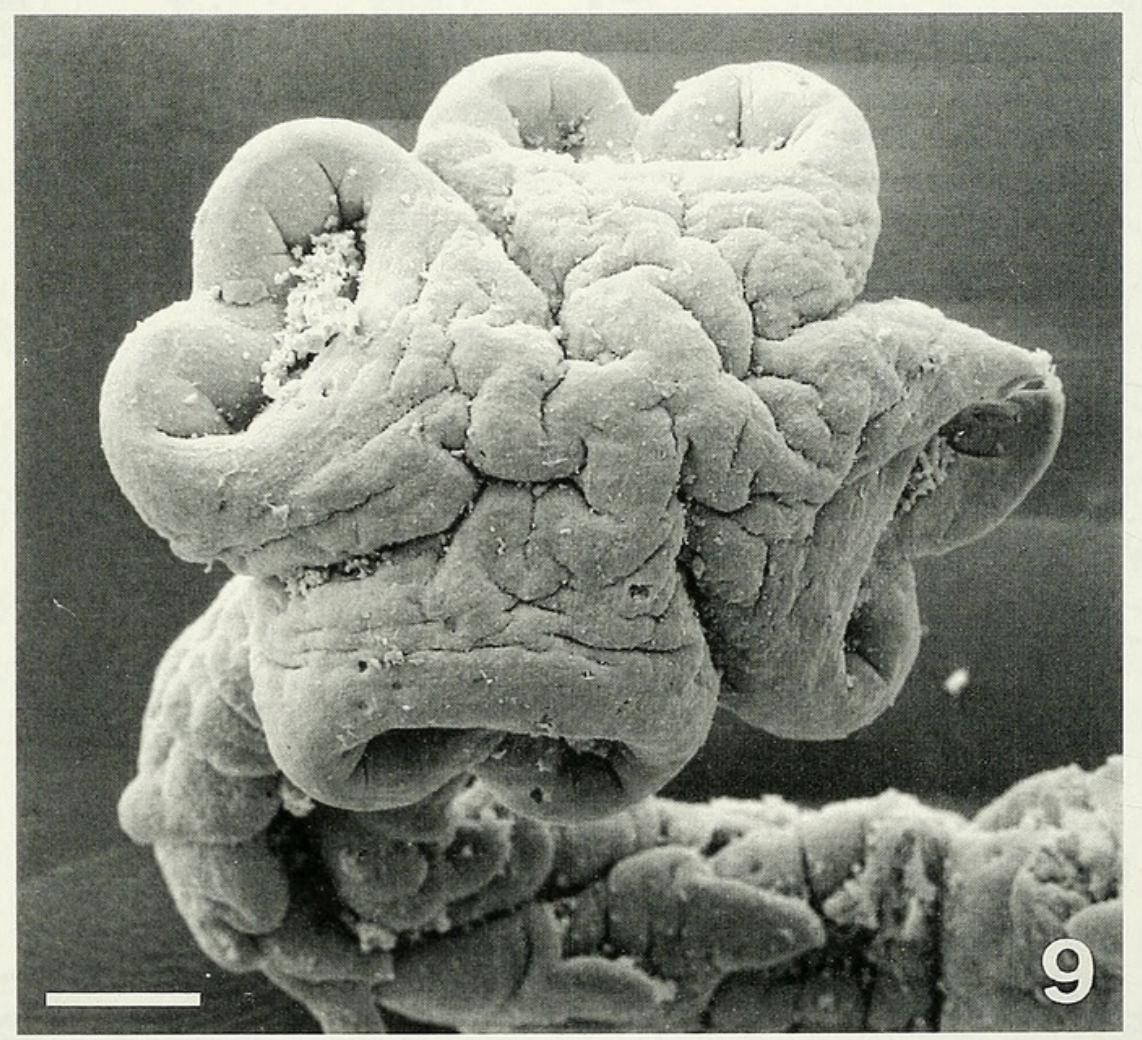

FIG. 9

Crepidobothrium eirasi $\mathrm{n}$. sp. Scolex. SEM apical view, showing apical tegumental folds. Scale = $100 \mu \mathrm{m}$. 
Eggs with delicate external membrane, 60-70 in diameter; external envelope ovoid, 14-16 x 18-20 in diameter, with two internal similar polar structures of different diameters: 7-9 and 4-5 respectively; embryophore 11-12 x 14 in diameter, oncosphere 8-10.5 in diameter, hooks 4-5 long (Figs 4, 7).

\section{DISCUSSION}

The medullar distribution of the genital organs, the paramuscular position of vitellaria and the heart-shaped structure of suckers suggests us for the present to allocate this species, at least provisionally, in the genus Crepidobothrium Monticelli, 1900, (Proteocephalinae) recently revised by one of the authors (see DE CHAMBRIER 1989a, b).

The new species is characterized by the following features: suckers heartshaped; presence of appendix at the ventral posterior edge on each side of proglottis; absence of vitellaria preporally and on anterior part of proglottis aporally; vitellaria paramuscular; uterus occupying the entire length of immature proglottis; eggs with two internal polar structures of different diameters.

The present new species differs from the five known species in this genus (Crepidobothrium gerrardii (Baird, 1860) parasite of Boa constrictor; C. dollfusi Freze, 1965 and C. lachesidis MacCallum, 1921, parasites of Eunectes murinus; C. viperis (Beddard, 1913) and C. garzonii de Chambrier, 1988, parasites of Bothrops alternatus) (Baird 1860; Beddard 1913; De Chambrier 1988; Freze 1965; MacCallum 1921) by the following characters: Absence of apical organ, presence of appendix at the ventral posterior edge on each side of proglottis, absence of preporal vitellaria, egg structure, smaller number of testes, small size of strobila.

C. eirasi n. sp. is the only species of the order Proteocephalidea having posterior ventral appendices on each proglottis. This structure is certainly not homologous with the overlapping of the posterior border of proglottis (craspedote morphology). Woodland (1935a), in his description of Myzophorus pirarara, did not mention the presence of appendices, in spite of the fact that specimens of $C$. eirasi n. sp. were present in his type material.

The absence of preporal vitellaria is rare in neotropical Proteocephalidae. Only Proteocephalus sophiae de Chambrier \& Rego, 1994 from Paulicea luetkeni and P. macdonaghi (Szidat \& Nani, 1951) from Basilichthys microlepidotus share this character with $C$. eirasi n. sp. (DE CHAMBrIER \& REgo 1994; SzIDAT \& NANI 1951).

The two internal polar ovoid structures of the eggs are unusual in proteocephalid cestodes. These structures look like two opercules, but a careful observation shows that they are located in the internal part of the external envelope.

The catfish Phractocephalus hemioliopterus has been recorded, uptonow in the Amazone basin, as host of the four following species: Zygobothrium megacephalum Diesing, 1850, Nomimoscolex pirarara (Woodland, 1935) (= Myzophorus pirarara Woodland, 1935) and Nomimoscolex woodlandi (Rego, 1984) (= Myzophorus woodlandi Rego, 1984) (see Rego \& Pavanelli 1992a, b). Crepidobothrium eirasi n. sp. is the fifth Proteocephalidea described from this host species. 
The weak longitudinal musculature is a common character to three species parasite of Phractocephalus hemioliopterus. Such a weak musculature makes it more difficult to determine of the medullar or cortical position of vitellaria, which characterize respectively the Proteocephalinae and the Zygobothriinae. In the beginning of the discussion, we expressed a reserve about the allocation of our species in the genus Crepidobothrium, and consequently in the Proteocephalinae, due to the intermediate position of vitellaria. The heart-shaped structure of the suckers was decisive to place $C$. eirasi $\mathrm{n}$. sp. in the genus Crepidobothrium.

\section{ACKNOWLEDGEMENTS}

We are grateful to Dr. Claude Vaucher (Geneva) for helpful discussions. We thank Nicolas Lekakis (Rio Mar Ldta, Itacoatiara) for his support in the field. We also thank Dr. Jean Wuest (Geneva) for SEM photographie.

\section{RESUMO}

É descrita uma nova espécie de proteocefalídeo, Crepidobothrium eirasi sp. n., parasita do peixe siluriforme pimelodídeo, Phractocephalus hemioliopterus. É a primeira referência de Crepidobothrium em peixes; as outras espécies foram descritas de serpentes da America do Sul. $C$. eirasi sp. n. pode ser caracterizada pelas suas reduzidas demensões (apenas 7-12 segmentos), pelas ventosas cordiformes, pelos apêndices do bordo posterior dos proglotes, pela distribuição dos folículos vitelinos, situados entre as fibras musculares e também externamente as mesmas, (paramuscular), além da ausência de vitelinos na região preporal dos proglotes.

\section{REFERENCES}

BAIRD, W. 1860. Description of some new species of intestinal Worms (Entozoa) in the collection of the British Museum. Proc. zool. Soc. Lond. 28: 446-448.

BEDDARD, F.E. 1913. Contributions to the anatomy and systematic arrangement of the Cestoidea. IX. On a new genus of Ichthyotaeniids. Proc. zool. Soc. Lond. 243-261.

DE CHAMBrIER 1988. Crepidobothrium garzonii n. sp. (Cestoda: Proteocephalidae) parasite de Bothrops alternatus Dum. Bibr. \& Dum. 1854 (Serpentes: Viperidae) au Paraguay. Revue suisse zool. 95(4): 1163-1170.

DE Chambrier 1989a. Révision du genre Crepidobothrium Monticelli, 1900 (Cestoda: Proteocephalidae) parasite d'Ophidiens néotropicaux. I. C. gerrardii (Baird, 1860) et $C$. viperis (Beddard, 1913). Revue suisse zool. 96(1): 191-217.

DE CHAMBrier 1989b. Révision du genre Crepidobothrium Monticelli, 1900 (Cestoda: Proteocephalidae) parasite d'Ophidiens néotropicaux. II. C. dollfusi Freze, 1965, C. lachesidis MacCallum, 1921) et conclusions. Revue suisse zool. 96(2): 345-380.

DE CHAMBrier 1990. Redescription de Proteocephalus paraguayensis (Rudin, 1917) (Cestoda: Proteocephalidae) parasite de Hydrodynastes gigas (Dum., Bibr. \& Dum., 1854) du Paraguay. Syst. Parasit. 16: 85-97. 
De Chambrier, A. \& Rego, A.A. 1994. Proteocephalus sophiae n. sp. (Cestoda: Proteocephalidae), a parasite of the siluroid fish Paulicea luetkeni (Pisces: Pimelodidae) from the Brazilian Amazon. Revue suisse Zool. 101(2): 361-368.

Freze, V.I. 1965. Essentials of Cestodology. Vol. V. Proteocephalata in Fish, Amphibians and Reptiles. Izdatel'stvo"Nauka", Moskva (Isr. Program Sci. Translations, Jerusalem. 1969.) $\mathrm{V}+597 \mathrm{pp}$.

MacCallum, G.A. 1921. Studies in Helminthology. Zoopathologica. 1(6): 137-284.

Rego, A.A. \& Pavanelli, G.C. 1992a. Checklist of the cestode order Proteocephalidea parasites from South America freshwater fishes. Revta Unimar, Maringa 14(Suppl.): 109-137.

Rego, A.A. \& Pavanelli, G.C. 1992b. Redescrição de Nomimoscolex admonticellia (Woodland), comb. n. (Cestoda: Proteocephalidea), parasito de Pinirampus pirinampu (Spix), um siluriforme de água doce. Revta. bras. Zool. 9(3/4): 283-289.

SzIDAT, L. \& NANI, A. 1951. Diplostomiasis cerebralis del Pejerrey. Una grave epizootia que afecta a la economia nacional producida por larvas de trematodes que destruyen el cerebro de los Pejerreyes. Revta Inst. nac. Invest. Cienc. nat. Mus. argent. Cienc. nat. "Bernardo Rivadavia" 1: 324-384.

WoodLAND, W.N.F. 1933a. On the anatomy of some fish cestodes decribed by Diesing from the Amazon. Q. J. microsc. Sci. 76(2): 175-208.

Woodland, W.N.F. 1933b. On two new cestodes from the Amazon siluroid fish Brachyplatystoma vaillanti Cuv. \& Val. Parasitology 25(4): 485-490.

WoodLand, W.N.F. 1933c. On a new subfamily of Proteocephalid cestodes - The Othinoscolecinae - from the Amazon Siluroid fish Platystomatichthys sturio (Kner). Parasitology 25(4): 491-500.

WoodLand, W.N.F. 1934a. On the Amphilaphorchidinae, a new subfamily of Proteocephalid cestodes, and Myzophorus admonticellia, gen. and sp. n., parasitic in Pirinampus spp. from the Amazon. Parasitology 26(1): 141-149.

WoodLAND, W.N.F. 1934b. On some remarkable new cestodes from the Amazon siluroid fish, Brachyplatystoma filamentosum (Lichtenstein). Parasitology 26(2): 268-277.

Woodland, W.N.F. 1934c. On six new Cestodes from Amazon Fishes. Proc. zool. Soc. Lond. 104(1): 33-44.

Woodland, W.N.F. 1935a. Additional Cestodes from the Amazon Siluroids Pirarará, Dorad, and Sudobim. Proc. zool. Soc. Lond. 104(4): 851-862 (1934).

Woodland, W.N.F. 1935b. Some more remarkable cestodes from Amazon siluroids fish. Parasitology 27(2): 207-225.

WoodLand, W.N.F. 1935c. Some new proteocephalids and a ptychobothriid (Cestoda) from the Amazon. Proc. zool. Soc. Lond. 105(3): 619-623. 


\section{$2 \mathrm{BHL}$ Biodiversity Heritage Library}

1995. "Crepidobothrium eirasi n. sp. (Cestoda: Proteocephalidae), a parasite of the siluroid fish Phractocephalus hemioliopterus (Schneider, 1801) (Pisces: Pimelodidae) from the Brazilian Amazon." Revue suisse de zoologie 102, 3-11. https://doi.org/10.5962/bhl.part.80457.

View This Item Online: https://www.biodiversitylibrary.org/item/128645

DOI: https://doi.org/10.5962/bhl.part.80457

Permalink: https://www.biodiversitylibrary.org/partpdf/80457

\section{Holding Institution}

Smithsonian Libraries

\section{Sponsored by}

Biodiversity Heritage Library

\section{Copyright \& Reuse}

Copyright Status: In Copyright. Digitized with the permission of the rights holder

Rights Holder: Muséum d'histoire naturelle - Ville de Genève License: http://creativecommons.org/licenses/by-nc-sa/3.0/ Rights: https://www.biodiversitylibrary.org/permissions/

This document was created from content at the Biodiversity Heritage Library, the world's largest open access digital library for biodiversity literature and archives. Visit BHL at https://www.biodiversitylibrary.org. 